\title{
Towards a Political Theory of Democratic Backsliding? Generalising the East Central European Experience
}

\author{
Ireneusz Pawet Karolewski
}

\section{INTRODUCTION}

Since December 2015, Poland has been considered the second East Central European (ECE) country, after Hungary, to be in the process of sliding back from democracy into authoritarianism. This assessment followed a series of reforms implemented by the national-conservative PiS (Law and Justice) government despite protests in the country and critique abroad. The most controversial reforms aimed at a radical reconstruction of the court system in Poland and mimicked similar developments that have taken place in Hungary under the national-conservative Fidesz (Hungarian Civic Alliance) government since 2010. Scholars of democracy have been convinced that both Viktor Orbán and Jarosław Kaczyński-the dominant political figures in both countries-abandoned liberal democracy, dismantled checks and balances and hoarded power in the hands of their party loyalists and cronies to exert partisan control over

I. P. Karolewski $(\bowtie)$

Leipzig University, Leipzig, Germany

e-mail: karolewski@uni-leipzig.de

(C) The Author(s) 2021

A. Lorenz and L. H. Anders (eds.), Illiberal Trends and Anti-EU Politics

in East Central Europe, Palgrave Studies in European Union Politics, https://doi.org/10.1007/978-3-030-54674-8_13 
public institutions (e.g. Sadurski 2018; Pech and Scheppele 2017). At the same time, both Fidesz and PiS have been able to generate high electoral support in national and European elections despite the recent authoritarian changes. The systemic changes have been accompanied by populist discourse promising to give the power back to "the true people" (Mudde and Kaltwasser 2017), claiming that liberal democracy after 1989 was an elite project amounting to a treachery of the Hungarian and Polish people by post-communist elites in league with the new liberal aristocracy and international bodies, such as the European Union (Sata and Karolewski 2019).

This strain of research suggests that the developments in East Central Europe are-due to the specifics of the transition process from communism to democracy-particular. However, similar developments, even though without the same degree of institutional change or the similar context of postcommunism, have been taking place in a number of other countries, both in Europe and beyond. Particularly striking are the cases of the US and the UK, that is, advanced and long-established democracies experiencing democratic backsliding themselves (Porritt 2019; Przeworski 2019; Dunleavy 2018; Huq and Ginsburg 2018). In both countries, populist post-truth rhetoric and disregard for liberal-democratic norms and institutions go hand in hand with attacks on checks and balances (Kaufman and Haggard 2019). Also, in the UK and the US, the once catch-all parties - the hitherto bearers of representative democracy-the Tories and the Republicans were able to secure majoritarian electoral support by embracing divisive and exclusionary policies (Huq and Ginsburg 2018).

In this perspective, Hungary and Poland can be regarded as part of a larger trend, rather than specific cases of democratic backsliding in weakly consolidated democracies where proper democracy has never really taken root. Against this background, this chapter argues that a general approach to democratic backsliding should be aimed for, rather than a strategy to identify only regional peculiarities, even though such certainly exist. I therefore suggest that a putative (rather than complete) theory of democratic backsliding should consider three aspects: (1) the societal one (what type of changes are underway with regard to the citizenry?), (2) the institutional one (what has been happening with the institutions of democratic government?) and (3) the processual one (what kind of process is democratic backsliding?). 
Firstly, after a brief literature discussion on democratic backsliding as a universal trend, I problematise the changed role of citizens from active and engaged ones towards spectatorship favouring authoritarian responses from leaders. Secondly, I argue that in institutional terms, democratic backsliding can be identified as state capture that occurs in different forms and might not always be properly reflected in the indices of democratic quality. Thirdly, I focus on the process of democratic backsliding itself which I call retrogression to semi-democracy.

\section{Democratic Backsliding as a Universal Trend}

At first glance, democratic backsliding could be understood as a reverse development to democratic consolidation, intensely discussed in the early 1990s, when ECE countries were on their road towards democracy. A number of transitologists argued at that time that the democratic consolidation in the transition countries could be simply measured by a number of democratic elections held in the transition country in question. For instance, according to Samuel Huntington, two consecutive democratic elections would be a reliable sign of a consolidated democracy (Huntington 1991, p. 266). However, the debates of the 1990s paid little attention to the possible breakdown of democratisation processes in ECE (and if they did, they focused on possible military or executive overthrows), as they were heavily influenced by the arguments put forward by Samuel Huntington (1991) and Francis Fukuyama (1989). Huntington argued that democratisation comes in waves which are observable throughout history and for that reason reflect a macro-historical pattern. This logic of history finds its Hegelian "end of history" in Fukuyama (1989), according to whom democracy is the ultimate telos of history with no alternatives. Fukuyama (1992, p. XI) argued that liberal democracy represents the "end point of mankind's ideological evolution" and the "final form of human government". Consequently, to many authorseven those with less of a Hegelian leaning-democracy became a sort of default position of any political system, towards which all types of regimes would naturally lean sooner or later. Additionally, modernisation theorists have come to believe that modernisation processes would support democratisation.

Even in the 1950s, Seymour Lipset (1959) believed in a causal relation between modernisation-measured by the number of telephones in a country-and the chances of democratic consolidation, while Samuel 
Huntington (1991, p. 313) determined a pro capita income of $\$ 500$ 1000, which would promote democratisation. In the modernisation perspective, the transition from the defunct real existing socialism and its "economy of shortage" towards a market economy might also propel modernisation processes, thus stabilising democracy (for the opposite view see, for instance, Przeworski 1991). Against this background, democratisation in newly established democracies would - even if initially in some cases-constitute a self-reinforcing rocky process. While focusing on new democracies, this understanding of authoritarian change largely ignored the very possibility of democratic backsliding in consolidated democracies of North America and Western Europe that were continuously regarded as the normative standard to be aspired to.

These linear ideas about democratic consolidation came under criticism in the light of recent challenges to democracy (e.g. Bustikova and Guasti 2017), which are, according to some authors, not only typical for the countries in ECE but rather reflect a global trend (e.g. Diamond 2015; Levitsky and Way 2002). In this view, the peculiarities of the post-communist transition to democracy-or even perhaps its historical uniqueness-do not necessarily imply that the democratic backsliding in the region has to be specific as well. As mentioned above, this global trend also includes the so-called advanced democracies like the US and the UK, which renders democratic backsliding almost a universal problem (Mounk 2018; Levitsky and Ziblatt 2018). The 2020 Democracy Report of the $\mathrm{V}$-Dem Institute markedly highlights this general trend as follows:

For the first time since 2001, there are more autocracies than democracies in the world. Hungary is no longer a democracy, leaving the EU with its first non-democratic Member State. India has continued on a path of steep decline, to the extent it has almost lost its status as a democracy. The United States - former vanguard of liberal democracy - has lost its way. (V-Dem Institute 2020)

The causes for global democratic backsliding are still being researched and the explanations include a number of hypotheses such as the growing polarisation of Western societies (Przeworski 2019), defunct political institutions (Norris and Inglehart 2019; Haggard and Kaufman 2016) and the failure of the political elites to address representation deficits of their political system (Albertus and Menaldo 2018; Levitsky and Ziblatt 
2018). Recently, Krastev and Holmes (2020) offered a rather counterintuitive explanation for the global democratic decline by using the concept of imitation. In this view, illiberalism in Eastern Europe (first of all in Russia, but afterwards in Hungary and Poland) is a "resentment-fueled" response to "the presumptively canonical status of Western political models after 1989" (Krastev and Holmes 2020, p. 13). However, it does not remain an Eastern European phenomenon, as the election of Donald Trump changes the direction of imitation. Now, the US is emulating Eastern illiberalism, whereas the rise of China seals the fate of liberal democracy as a global normative standard.

I argue that the democratic decline is to be found across the globe due to the fragility of liberal democracy itself, rather than, for instance, as a result of a sequential imitation process. The "authoritarian diffusion" thesis has been falsified with regard to its inspirational movement from Russia to Hungary (Buzogány 2017) and seems to be doubtful of the US under Donald Trump being inspired by the developments in ECE. On the contrary, the oldest and (arguably) most advanced democracies-the UK and the US-have fallen prey to chauvinist populism, post-truth politics and attacks on institutions of liberal democracy (Huq and Ginsburg 2018; Freedom House 2019; Przeworski 2019) regardless of the developments in ECE. The UK and the US have been long viewed as the democratic standard for countries in transition to democracy, for instance, in the seminal civic culture study of the 1960s (Verba and Almond 1963). Systemically, this development is more remarkable than the progressing authoritarianism of Russia or Turkey, since it goes against the basic assumptions of research in democracy theory.

While the illiberal developments in the US and the UK have been a surprise to many observers, one can find certain clues about a principle fragility of democracy in some political theory writings. For instance, Gabriel Almond in his early work in the 1950s expresses serious doubts about some Western democracies (he calls them "continental democracies" in contrast to "Anglo-Saxon democracies" and means mainly France and Italy as opposed to the UK) remaining democratic, as he ascribes "Caesaristic breakthroughs", that is, authoritarian tendencies, to these countries (Almond 1956, p. 408). Almond claims that "fragmented political cultures" and "immobilism" in Western countries make these democratic regimes less stable and prone to authoritarian or even totalitarian fractures: 
[...] These systems tend always to be threatened by, and sometimes to be swept away by, movements of charismatic nationalism which break through the boundaries of the political sub-cultures and overcome immobilism through coercive action and organization. In other words, these systems have a totalitarian potentiality in them. The fragmented political culture may be transformed into a synthetically homogeneous one and the stalemated role structure mobilized by the introduction of the coercive pattern [...]. (Almond 1956, p. 408)

In this view, some democracies are principally prone to break down and others are structurally stable. Nowadays, Almond's optimistic belief in the Anglo-Saxon democracies is certainly unjustified. Whether democratic backsliding is a result of a specific "fragmented culture", as Almond suggested, is also disputed, since he apparently viewed culture as an unchangeable dichotomous structure, either endangering democracies or stabilising them. However, political developments can also affect cultures, rather than just reflecting them. Peter Wilkin argues in exactly this vein, when he says that "Hungary's current Orbánisation reflects an on-going tension between liberal and illiberal tendencies, the latter being part of the foundations of the modern world-system" (Wilkin 2018, p. 5). Moreover, Almond's differentiation of democracies that are structurally endangered and those that are stable by nature is of limited use. Instead, I would argue that we should identify democratic backsliding as a process, which can occur in every democracy but not necessarily to the same degree. In this sense, democratic backsliding would be a category of degree, rather than a category of kind. If democratic backsliding means gradual weakening of democracy, Hungary, for instance, can be viewed as an example of a more general trend, albeit one of the more pronounced cases thereof (Ágh 2016).

The degree/nature of democratic backsliding is also highlighted in more contemporary literature in political theory. For instance, Nadia Urbinati $(2014,2019)$ points out that all democracies (including the advanced ones) are subject to three potential disfigurations while the formal institutions of democracy can remain more or less intact: the epistemic disfiguration, the populist disfiguration and the plebiscitary disfiguration (Urbinati 2014, p. 8). The epistemic disfiguration frames democracy as a system of knowledge, in which mainly competent elites can make political decisions according to specific knowledge, and by doing so, they treat politics as a quasi-technical area to be removed from 
mass politics. The populist disfiguration claims the will of the people for one specific group while excluding others (Urbinati 2014, p. 131). The plebiscitary disfiguration means that representative democracy is reduced to plebiscitary forms of citizens' participation. In this view, citizens become an audience observing the political decision-makers, rather than controlling them at the ballot box. These three disfigurations can occur to various degrees and even stop short of democratic backsliding, in case there is no change in the institutional set-up of a democratic regime. While I am not going to discuss Urbinati's "disfiguration approach" in full detail, I do take her "audience democracy" (or plebiscitary disfiguration) as a point of departure to argue that a political theory of democratic backsliding should consider three aspects: the societal (changes in the society), the institutional (changes in the institutional set-up of democracies) and the processual (the process of democratic backsliding itself).

\section{The Societal: The Rise of Audience Democracy}

Political leaders do not always "hijack" democratic institutions generating democratic backsliding; they often modify them within the constraints imposed by institutions and with the support of voters. In this sense, political backsliding can thrive on how the citizenry behaves. To Nadia Urbinati, one of the key issues thereof is that citizenry becomes an audience acting through plebiscites on the popularity of politicians. Politicians are "in the eyes of the people", but at the same time, the citizens become passive by watching their leaders. This audience democracy replaces democratic accountability with popularity and the citizens are often likely to fall under the spell of authoritarian leaders who make the citizens react to political decisions in a yes or no manner: "The Roman plebiscitum was a yes-no decision by the plebs to a proposal that came from the tribune of the plebs" (Urbinati 2014, p. 176).

Audience democracy results from the alteration of traditional forms of political participation, such as party membership, engagement into party politics and electoral voting. Sadurski (2018) points this out with regard to Poland with the following argument:

Poland has one of the lowest numbers of party membership in Europe (only approx. 1 percent of the adult population, compared to $2.3 \%$ in Germany and $3.8 \%$ in Sweden); party loyalties by voters are extremely shallow and devoid of strong value meanings (e.g. 18\% of those who 
voted in 2011 for a left-wing SLD transferred their votes in 2015 to a right-wing $\mathrm{PiS}$ ), and the dominant phenomenon of societal mobilisation in recent years was about single-issue protests, which were often episodic and non-institutionalised (e.g. about ACTA or the anti-abortion legislative initiative). (Sadurski 2018, p. 111)

This resonates with the current debate on citizenship, in which changes to how citizens see their role in politics are highlighted. In his widely discussed book "The People vs Democracy", Yasha Mounk (2018, p. 100) argues that the crisis of democracy is (among others) correlated with citizens' low interest in politics-particularly visible in young people-and their growing support for non-democratic regimes in the US (Mounk 2018, p. 105). Even though the picture is more complicated in Europe, Mounk suggests that increasingly more citizens are more open to non-democratic regime alternatives including military, technocratic and technological solutions. Particularly young people are more likely to wish for a technocratic dictatorial figure like Steve Jobs who would treat politics like a software problem-a sort of "Silicon Valley syndrome"enforcing the best solutions. In this view, politics is perceived to be a question of a proper technical design, rather than citizens' participation, the latter being a problem of finding optimal solutions. In this vein, the European Tech Insights (Center for the Governance of Change 2019) found that $25 \%$ Europeans favour letting an artificial intelligence make important political decisions about their own country. In countries such as the Netherlands, Germany and the UK, the percentage is even higher, as it reaches $30 \%$. Interestingly, this preference is stronger with people who have university degrees (Center for the Governance of Change 2019, p. 11).

As John R. Hibbing and Elizabeth Theiss-Morse (2004, p. 4) argue, the citizenry as a whole tends to be quite indifferent to policy-making and therefore are not eager to hold the government accountable for its policies. Still, the people want to control the government but only under rare circumstances when they think politicians might benefit from citizens. Citizens just want to have the feeling that they can potentially control the government but the bulk of citizens do not have any "current intention of getting involved in government or even of paying attention to it". In sum, citizens dislike sustained public involvement but want to have the illusion of control. Thus, Hibbling and Theiss-Morse refute the 
widespread assumption that participatory democracy is the ultimate goal and preference of citizens.

Instead, we might be witnessing a transformation towards an audience democracy. Some authors think that this type of "ocular democracy" allows for a better control of the leaders. For instance, Jeffrey Edward Green (2010) stresses that citizens as spectators can effectively control the everyday performance of the politicians. While Green developed his argument prior to Trump's ascent to presidency (with Trump being the perfect embodiment of celebrity-cum-politician), he clearly misapprehended the consequences of citizens being spectators. While Greene agrees that citizens are disinclined to rule themselves and want to be ruled instead, he claims that the spectatorship of "ocular democracy" can be an alternative form of democratic power, as leaders placed in conditions of publicity are more likely to reveal the truth about their intentions-a colossal misjudgement in times of post-truth politics.

On the contrary, I would argue that we can observe less democratic control of the leaders and more audience democracy (Mishra 2017). The spectators can be easily manipulated into politics of insecurity and exclusionary identity politics, which in fact occurs during democratic backsliding (Sata and Karolewski 2019). Citizens as spectators watch politicians in their spectacles organised specifically for the people. The spectacles operate through scandalisation and propaganda, in which the questions of political accountability are replaced by media interest in the private lives of politicians, their family matters and other trivia. This is not a new insight, as already in the 1990s (long before a Reality TV celebrity became US President) Thomas Mathiesen coined the concept of "the viewer society" (Mathiesen 1997). It is a further power mechanism supplementing the panopticon (the few people watch the many). But other than panopticon, synopticon seduces people into watching, rather than coercing them. In this way, citizens are replaced by spectators.

However, watching the leaders is not necessarily a mechanism of controlling politicians by the masses, as it promotes leaders who in fact strive for mass support through television and other forms of mass communication, such as Twitter. In an audience democracy, leaders often seek direct contact with the spectators, while undercutting power limitation and the division of power (Urbinati 2014, p. 174). As Urbinati points out, Hugo Chávez spent apparently 1500 hours criticising capitalism on a TV show, while Silvio Berlusconi was present on various TV channels on a daily basis during his years as Prime Minister. Moreover, 
the audience is not only seduced into watching their leaders. They are also subjected to politics of insecurity and exclusionary identity politics, which are crucial for the support of democratic backsliding. In the politics of insecurity, the citizen-cum-spectator is often confronted with threat scenarios highlighting his/her shared destiny and group belonging. This promotes neurotic citizens (Isin 2004) who define politics in terms of its permanent insecurity and threat scenarios. Their preference for liberty and participation becomes surpassed by fears of survival in view of organised criminality, possible terrorist attacks, treachery and international conspiracies (e.g. Mancosu et al. 2017). As a consequence, citizens focus more strongly on reporting potentially dangerous situations and spying on other citizens, rather than on elections, public space and ensuring the accountability of the government (e.g. Douglas and Sutton 2018; Moore 2016). Furthermore, the audience democracy favours demarcation and a juxtaposition of the in-group in relation to the "other". Through mass communication, leaders activate the "others" in the perception of the spectators, since the binary construction of "us" versus "them" allows for blaming and scapegoating strategies.

These developments might not constitute democratic backsliding itself and do not exclude traditional political activity by citizenry. An exact turning point of citizens' democracy into spectators' democracy is rather difficult to establish and it needs to be explored empirically, rather than a priori. However, a progressing audience democracy favours democratic backsliding, as the transformation of citizenry into audience promotes the plebiscitary democracy, in which citizens watch their leaders and accept their prior decisions. This is in tune with what Joseph A. Schumpeter (2006/1942, pp. 284-285) claimed democracy really is: "Democracy means only that the people have the opportunity of accepting or refuting the men who are to rule them".

\section{The Institutional: Looking for State Capture}

While audience democracy seems to facilitate democratic backsliding by transforming parts of the society into spectators, state capture is the main institutional feature of democratic backsliding. Fukuyama (2014, p. 54) describes state capture as "the capture of ostensibly impersonal state institutions by powerful elites". It occurs in many democracies to a varying degree. State capture occurs when political and economic actors take over 
the institutions of the state and misuse them for their own narrow political and economic interests.

The government ceases to represent the societal interests and becomes a tool of influence in favour of vested interests subverting democratic decision-making processes. This can be viewed already as problematic in the case of corporate lobbying, particularly when it lacks accountability and transparency. It becomes even more problematic when, for instance, courts are used for the harassment of political opponents, anti-corruption agencies are disabled to undermine investigations against corrupt politicians in power or tax authorities are ill-used to secure tax deductions for oligarchs (who also exist in advanced democracies). This goes beyond simple clientelism (prevalent in many democracies), as the "hollowing out" of state institutions ensues and economic rents or partisan power are extracted from them (Grzymala-Busse 2008). The concept has largely been used in the research on financial-political networks in Russia and Ukraine, where economically powerful actors during the transition time colonised state institutions to promote their private business interests (e.g. Yakovlev and Zhuravskaya 2006). A prime example of state capture was the presidency of Viktor Yanukovych (2010-2014), during which oligarchs' interests thrived symbiotically in league with the kleptocratic regime, until the Euromaidan revolution ended it.

Against this backdrop, Abby Innes (2014, p. 88) identifies two clusters of state capture in ECE based on two modes of dominance over state institutions: the party state capture (monopoly of a party exploiting significant state institutions for partisan gain, including courts, office of the general prosecutor and government agencies) and corporate state capture where public power is exercised mainly for private gain. In this regard, the Czech Republic, Slovakia, Romania and Bulgaria present cases of corporate state capture, whereas Hungary and Poland stand for party state capture-a re-monopolisation of the political system in favour of a party in power (Sata and Karolewski 2019; for an alternative typology, see Stanley 2019). Certainly, party state capture does exclude corporate state interests encroaching political institutions and vice versa. Parties can (and they do) become vehicles for personal enrichment (Hungary and Poland) and corporate interests can form political parties (the Czech Republic). Still, these two ideal types of state capture show distinct features that can explain specific behaviour of governments in democratic backsliding. A corporate capture aims at weakening or disabling policies, as it wants to suppress the activity of the state. It is also less likely to be interested 
in changing the ideological core of policies but rather seeks institutional and policy stability, reflecting static corporate demands (e.g. the "the state as a firm" ideology by Andrej Babiš in the Czech Republic, see Bustikova and Guasti 2019). In contrast, party state capture intensifies policy implementation and responsiveness because party preferences are immediately turned into policies (e.g. the controversial decommunisation policies of PiS) (Sata and Karolewski 2019). The distinction between party state capture and corporate state capture can also explain why party state capture is more visible in the public space, because the institutional set-up of the state is subject to radical change. For that reason, international actors like the EU or the Council of Europe react mainly to the party state capture, rather than to the less visible corporate state capture.

The corporate state capture attempts to avoid the limelight, as it is based on problematic networks between economic and political interests, which do not want to be discovered. The party state capture undermines the independence of state institutions in the open, while backing it up with the propaganda of identity politics. The corporate state capture prefers secrecy to the public space, as it undercuts state institutions through their adaptation to the oligarchic interests. This is not only the case in ECE as we can observe plenty of examples of corporate state capture in the US since 2016. For instance, Donald Trump has been using state resources extensively to advance interests of his firm and his family, by placing his daughter and her husband in the White House system of decision-making and compelling state employees and foreign leaders to spend money in his hotels and resorts (e.g. Fahrenthold et al. 2020). Trends of party state capture are visible in the UK under the Boris Johnson government, for instance, with regard to the plans of the government to strip the BBC (as an independent source of information for citizens) of its funding (Cowburn 2020). This goes hand in hand with the support for Brexit and the Johnson government by Rupert Murdoch and his media empire.

While one of the differences between both types of state capture lies in their public visibility, they do not necessarily differ in their challenges to democracy. However, with corporate state capture, the relevant democracy quality indices (e.g. Freedom House) appear to be helpless, as they are unable to entirely reflect it. This also goes for the European Union that deals mainly with the institutional changes in Poland, Hungary and Romania (albeit not very successfully), while ignoring corporate state capture in other countries. As Hanley and Vachudova (2018, p. 276) 
show, in contrast to Hungary and Poland, democratic backsliding in the Czech Republic lacks a powerful nationalist narrative, but there are crucial similarities with regard to tactics and forms of power concentration. Babiš and his party ANO use a technocratic rationale ("state as a firm"), but the goal is the same-hoarding state power and abolishing checks and balances. In the Czech Republic, it happens in the name of efficiency and modernisation, rather than in the name of bringing the power back to the people (Hanley and Vachudova 2018, p. 289).

\section{The Processual: Retrogression TOWARDS SEMI-DEMOCRACY}

De-democratisation does not have to occur as a result of a military coup or a revolution. In many cases, it is a consequence of actions by democratically elected actors (Luo and Przeworski 2019). In this perspective, the challenges to democracy are likely to arise from the political elites themselves, even from the political mainstream (see Hungary, Poland and the US), rather than the military (like in Argentina in 1976) or foreign powers (like in Iran in 1953). As opposed to abrupt de-democratisation, democratic backsliding takes place in the process of little steps including political changes of formal and informal nature. As a result, civil rights, democratic elections and democratic accountability are eroded, rather than abolished overnight, which can take years, rather than days. This can apply to unwritten norms of democratic decision-making, such as abstention of the executive branch from influencing court decisions or limiting the rights of the opposition in law-making by using fast-track decision procedures under actual exclusion of opposition. All these changes have the goal of limiting political competition and hoarding power with the goal of skewing the political system to increase the chances of remaining in power for the incumbent actors (Waldner and Lust 2018).

Since the process of backsliding is not as abrupt as a military or executive coup, it is difficult to determine the tipping point, at which democracy ceases to be democracy. Usually, it takes a number of controversial laws and changes in the constitutional set-up-mainly the court system - that propel the process of democratic backsliding; the damage to liberal democracy can be seen only after these changes took an aggregated effect (Sadurski 2018, p. 5). The issue here is not an incremental constitutional change in democracies, which is the rule, but a series of problematic laws that are already individually controversial. Still, none of these laws 
constitute regime changes comparable to, for instance, the Enabling Act of 1933 that gave Hitler plenary powers to enact laws without the involvement of the Reichstag (and which, together with the Reichstag Fire Decree, abolished most civil liberties in the interwar Germany).

As opposed to authoritarian overthrows based, for instance, on rigged elections or intimidation of political opposition through unlawful imprisonment or show trials (see Russia or Turkey), democratic backsliding often occurs as a result of systematic attacks on the rule of law and/or sweeping reforms of the court system, whereas elections still take place and opposition is free to organise itself. In this perspective, constitutions cannot protect democracies from democratic backsliding, since the very functioning of the constitutional institutions such as the constitutional or supreme courts are undermined without the need of formally changing constitutions. For instance, the functionality (or rather dysfunctionality) of a constitutional court can be achieved through court packing, that is, a modification in the number of judges allowing friendly judges and party loyalists to be put on the bench. Should independent courts come under the control of the government, they are often turned into tools for further democratic erosion, which can be labelled "oppressive constitutionalism". In 2004, the number of judges of the Supreme Court in Venezuela was increased from 20 to 32 , with the goal of changing the majority in favour of the government. In Bolivia, the president initiated an impeachment procedure against three judges of the Constitutional Court in 2014. The procedure was based on trumped-up charges but the president succeeded in removing the judges in question (Landau and Dixon 2019). In this regard, the development towards oppressive constitutionalism (Tushnet 2014) is likely to be a further central feature of democratic backslidingquite the opposite of what the hopes of democratic constitutionalism in the early 1990s were (e.g. Elster 1991).

Freedom House has identified similar developments in the US since 2016, where the president and his supporters consistently attacked independent courts, the judiciary and law enforcement, while eroding public trust in independent media and the rule of law:

The [US] president has since urged the Department of Justice to prosecute his political opponents and critics. He has used his pardon power to reward political and ideological allies and encouraged targets of criminal investigations to refuse cooperation with the government. (Freedom House 2019, p. 20) 
While such developments alone might not constitute a breakdown of democracy, they can be understood as retrogression in contrast to reversion, the latter being a rapid collapse of democratic institutions. The concept of retrogression has been introduced by Huq and Ginsburg (2018) to describe "a more subtle, incremental erosion to three institutional predicates of democracy occurring simultaneously: competitive elections; rights of political speech and association; and the administrative and adjudicative rule of law". The key issue here is that no democracy is perfect and there are sometimes some violations of democracy, such as political corruption or problematic corporate lobbying. However, a series of such incremental violations in their aggregate effect can constitute a qualitative regime change subverting the very functioning of democracy without abolishing formal democratic institutions, such as cyclical elections. As Huq and Ginsburg (2018, p. 118) argue: "The precise point, however, at which the volume of democratic and constitutional backsliding amounts to constitutional retrogression will be unclear-both ex ante and contemporaneously". Against this backdrop, I argue that the outcome of such development can be called semi-democracy, which is a regime that uses constitutional and democratic forms but in fact operates through significant violations of democratic rule, in particular the rule of law.

Semi-democracies guarantee free elections and refrain from the imprisoning of political opponents (even though the opponents can be harassed by use of court trials, politically motivated prosecutor's measures and targeted controls by tax authorities). In this sense, semi-democracies are distinguishable from electoral autocracies, in which elections are subject to severe manipulation and opposition politicians undergo systematic repressions (Schedler 2013, p. 3). In semi-democracies, opposition forces still have a chance of winning elections and regaining the power, which is impossible without a revolt or a regime breakdown in electoral autocracies. $^{1}$

${ }^{1}$ There are a number of adjacent concepts, such as defective democracy (e.g. Merkel 2004) or semi-consolidated democracy (e.g. Acemoglu and Robinson 2001). They all suffer from problems of "democracy with adjectives", broadly debated in the transition theory some time ago. One of the conceptual problems of "democracy with adjectives" is that this notion implies that we deal with imperfect democracies (probably on their way towards fully fledged democracy), rather than distinct and stable regimes, such as semi-democracy (Collier and Levitsky 1997; Knobloch 2002). 
Of all transitologists, Guillermo O'Donnell (1992, p. 19) and Samuel P. Huntington (1996) pointed to the possibility of the "slow death" of democracy, which was described as "a progressive diminution of existing spaces for the exercise of civilian power and the effectiveness of the classic guarantees of liberal constitutionalism". This democradura could still be able to secure electoral support, in particular through usage of plebiscitary instruments, such as referenda (see also Schedler 1998). Samuel P. Huntington also agreed that gradual democratic erosion would be more likely than an abrupt democratic breakdown in the third-wave democracies: "Threats to third-wave democracies are likely to come not from generals and revolutionaries who have nothing but contempt for democracy, but rather from participants in the democratic process. These are political leaders and groups who win elections, take power, and then manipulate the mechanisms of democracy to curtail or destroy democracy" (Huntington 1996, p. 8). Still, Huntington did not see any similar dangers of democratic backsliding in advanced democracies nor did he explore the conditions or paths of this type of democratic backsliding.

\section{Conclusions}

I have argued in this chapter that a putative theory of democratic backsliding should consider the societal, the institutional and the processual aspects. Regarding the societal aspect of democratic backsliding, I have pointed out that changes in the nature of citizenship towards spectatorship, passivity and plebiscitary understanding of democracy favour democratic backsliding, even though they might not constitute democratic backsliding on their own.

Considering the institutional aspect, I have focused on state capture, which I argue is the central feature of democratic backsliding. I have here applied the two-type differentiation: the party state capture and the corporate state capture, the latter discernable, for instance, in the Czech Republic and the US, while the former is more typical for Poland and Hungary. Even though these are ideal types, the difference between the party state capture and corporate state capture is not only of conceptual value, as some indices of democratic quality have difficulties reflecting the corporate state capture.

With regard to the processual aspect, democratic backsliding does not necessarily lead to fully fledged authoritarianism but rather constitutes a retrogression to semi-democracy, in which the dismantling of relevant 
liberal-democratic institutions such as the rule of law goes hand in hand with cyclical elections preserving democratic standards in a broader sense (see also Chapters 1 and 14). This semi-democracy draws its legitimacy from electoral support but it can also lose it, paving a way for a return to liberal democracy.

I have also argued that democratic backsliding can occur in advanced democracies, which has actually been happening, for instance, in the US, though not to the same degree as in Hungary and Poland. In sum, I posit that we need to look at democratic backsliding as a category of degree, rather than kind, with a turning point between democracy and autocracy that is difficult to identify. Nevertheless, democratic backsliding can lead to semi-democracy as a stable outcome, rather than electoral authoritarianism.

\section{REFERENCES}

Acemoglu, D., and J.A. Robinson. 2001. A Theory of Political Transitions. The American Economic Review 91 (4): 938-963.

Ágh, Attila. 2016. The Decline of Democracy in East-Central Europe. Problems of Post-Communism 63 (5-6): 277-287.

Albertus, Michael, and V. Menaldo. 2018. Authoritarianism and the Elite Origins of Democracy. Cambridge: Cambridge University Press.

Almond, Gabriel A. 1956. Comparative Political Systems. The Journal of Politics 18 (3): 391-409.

Bustikova, L., and P. Guasti. 2017. The Illiberal Turn or Swerve in Central Europe? Politics and Governance 5 (4): 166-176.

Bustikova, L., and P. Guasti. 2019. The State as a Firm: Understanding the Autocratic Roots of Technocratic Populism. East European Politics and Societies 33 (2): 302-330.

Center for the Governance of Change. 2019. European Tech Insights: Mapping European Attitudes to Technological Change and Its Governance. https://docs. ie.edu/cgc/European-Tech-Insights-2019.pdf. Accessed 9 April 2020.

Buzogány, Aron. 2017. Illiberal Democracy in Hungary: Authoritarian Diffusion or Domestic Causation? Democratization 24 (7): 1307-1325.

Collier, D., and S. Levitsky. 1997. Democracy with Adjectives: Conceptual Innovation in Comparative Research. World Politics 49 (3): 430-451.

Cowburn, Ashley. 2020. Tory MPs Turn on Boris Johnson over Plot to 'Destroy' the BBC. The Independent. https://www.independent.co.uk/news/uk/pol itics/boris-johnson-bbc-license-fee-tories-netflix-a9338631.html. Accessed 9 April 2020. 
Diamond, Larry. 2015. Facing Up to the Democratic Recession. Journal of Democracy 26 (1): 141-155.

Douglas, K.M., and R.M. Sutton. 2018. Why Conspiracy Theories Matter: A Social Psychological Analysis. European Review of Social Psychology 29 (1): 256-298.

Dunleavy, Patrick. 2018. Auditing the UK's Changing Democracy. In The UK's Changing Democracy: The 2018 Democratic Audit, ed. P. Dunleavy, A. Park, and R. Taylor, 15-42. London: LSE Press.

Elster, Jon. 1991. Constitutionalism in Eastern Europe: An Introduction. University of Chicago Law Review 58 (2): 447-482.

Fahrenthold, D.A., J. O'Connell, C.D. Leonning, and J. Dawsey. 2020. Secret Service Has Paid Rates as High as $\$ 650$ a Night for Rooms at Trump's Properties. The Washington Post. https://www.washingtonpost.com/politics/ secret-service-has-paid-rates-as-high-as-650-a-night-for-rooms-at-trumps-pro perties/2020/02/06/7f27a7c6-3ec5-11ea-8872-5df698785a4e_story.html. Accessed 9 April 2020.

Freedom House. 2019. Freedom in the World 2019: Democracy in Retreat. Washington, DC. https://freedomhouse.org/sites/default/files/Feb2019_FH_F ITW_2019_Report_ForWeb-compressed.pdf. Accessed 9 April 2020.

Fukuyama, Francis. 1989. The End of History? The National Interest 16: 3-18. Fukuyama, Francis. 1992. The End of History and the Last Man London. New York: The Free Press.

Fukuyama, Francis. 2014. Political Order and Political Decay: From the Industrial Revolution to the Globalization of Democracy. New York: Farrar, Straus and Giroux.

Green, Jeffrey E. 2010. The Eyes of the People: Democracy in an Age of Spectatorship. Oxford: Oxford University Press.

Grzymala-Busse, Anna. 2008. Beyond Clientelism: Incumbent State Capture and State Formation. Comparative Political Studies 41 (4-5): 638-673.

Haggard, Stephan, and R.R. Kaufman. 2016. Dictators and Democrats: Masses, Elites, and Regime Change. Princeton: Princeton University Press.

Hanley, Seán, and Milada Anna Vachudova. 2018. Understanding the Illiberal Turn: Democratic Backsliding in the Czech Republic. East European Politics 34 (3): 276-296.

Hibbing, John R., and Elizabeth Theiss-Morse. 2004. Stealth Democracy: Americans' Beliefs About How Government Should Work. Cambridge: Cambridge University Press.

Huntington, Samuel P. 1991. The Third Wave: Democratization in the Late Twentieth Century. Norman: University of Oklahoma Press.

Huntington, Samuel P. 1996. Democracy for the Long Haul. Journal of Democracy 7 (2): 3-13. 
Huq, A., and T. Ginsburg. 2018. How to Lose a Constitutional Democracy. U.C.L.A. Law Review 65: 78-169.

Innes, Abby. 2014. The Political Economy of State Capture in Central E Urope. JCMS: Journal of Common Market Studies 52 (1): 88-104.

Isin, Engin F. 2004. The Neurotic Citizen. Citizenship Studies 8 (3): 217-235.

Kaufman, R.R., and S. Haggard. 2019. Democratic Decline in the United States: What Can We Learn from Middle-Income Backsliding? Perspectives on Politics 17 (2): 417-432.

Knobloch, Jörn. 2002. Defekte Demokratie oder keine? Das politische System Russlands. Münster: LIT.

Krastev, Ivan, and S. Holmes. 2020. The Light That Failed: Why the West Is Losing the Fight for Democracy. New York: Pegasus Books.

Landau, D., and R. Dixon. 2019. Abusive Judicial Review: Courts Against Democracy. 53 UC Davis Law Review, Public Law Research Paper 907.

Levitsky, Steven, and D. Ziblatt. 2018. How Democracies Die. New York: Broadway Books.

Levitsky, S., and L.A. Way. 2002. Elections without Democracy: The Rise of Competitive Authoritarianism. Journal of Democracy 13 (2): 51-65.

Lipset, Seymour M. 1959. Some Social Requisites of Democracy. American Political Science Review 53 (1): 69-105.

Luo, Z., and A. Przeworski. 2019. Subversion by Stealth: Dynamics of Democratic Backsliding. https://ssrn.com/abstract=3469373. Accessed 9 April 2020.

Mancosu, M., S. Vassallo, and C. Vezzoni. 2017. Believing in Conspiracy Theories: Evidence from an Exploratory Analysis of Italian Survey Data. South European Society and Politics 22 (3): 327-344.

Mathiesen, Thomas. 1997. The Viewer Society: Michel Foucault's 'Panopticon' Revisited. Theoretical Criminology 1 (2): 215-234.

Merkel, Wolfgang. 2004. Embedded and Defective Democracies. Democratization 11 (5): 33-58.

Mishra, Pankaj. 2017. Age of Anger: A History of the Present. New York: Farrar, Straus and Giroux.

Moore, Alfred. 2016. Conspiracy and Conspiracy Theories in Democratic Politics. Critical Review: A Journal of Politics and Society 28 (1): 1-23.

Mounk, Yascha. 2018. The People vs. Democracy: Why Our Freedom Is in Danger and How to Save It. Cambridge: Harvard University Press.

Mudde, Cas, and C.R. Kaltwasser. 2017. Populism: A Very Short Introduction. Oxford: Oxford University Press.

Norris, Pippa, and R. Inglehart. 2019. Cultural Backlash: Trump, Brexit, and Authoritarian Populism. Cambridge: Cambridge University Press.

O'Donnell, Guillermo. 1992. Transitions, Continuities, and Paradoxes. In Issues in Democratic Consolidation: The New South American Democracies 
in Comparative Perspective, ed. S. Mainwaring, G. O'Donnell, and J.S. Valenzuela, 17-56. Notre Dame: University of Notre Dame Press.

Pech, L., and K.L. Scheppele. 2017. Illiberalism within: Rule of Law Backsliding in the EU. Cambridge Yearbook of European Legal Studies 19: 3-47.

Porritt, Luisa. 2019. Britain's Democratic Gap: It's Ironic the British Government Insists EU Is 'Undemocratic' as It Loses Sight of Its Own Values. Politico. https://www.politico.eu/article/britain-democracy-gap-brexit-mepeu-uk-liberal-democrats-boris-johnson/. Accessed 9 April 2020.

Przeworski, Adam. 1991. Democracy and the Market: Political and Economic Reforms in Eastern Europe and Latin America. Cambridge: Cambridge University Press.

Przeworski, Adam. 2019. Crises of Democracy. Cambridge: Cambridge University Press.

Sadurski, Wojciech. 2018. How Democracy Dies (in Poland): A Case Study of Anti-constitutional Populist Backsliding. Revista Forumul Judecatorilor 1: 104-178.

Sata, R., and I.P. Karolewski. 2019. Caesarean Politics in Hungary and Poland. East European Politics, 1-20.

Schedler, Andreas. 1998. What Is Democratic Consolidation? Journal of Democracy 9 (2): 91-107.

Schedler, Andreas. 2013. The Politics of Uncertainty: Sustaining and Subverting Electoral Authoritarianism. Oxford: Oxford University Press.

Schumpeter, Joseph A. 2006/1942. Capitalism, Socialism and Democracy. London: Routledge, published by Harper \& Brother in 1942.

Stanley, Ben. 2019. Backsliding Away? The Quality of Democracy in Central and Eastern Europe. Journal of Contemporary European Research 15 (4): 344353.

Tushnet, Mark. 2014. Authoritarian Constitutionalism. Cornell Law Review 100 (2): 391-462.

Urbinati, Nadia. 2014. Democracy Disfigured. Cambridge: Harvard University Press.

Urbinati, Nadia. 2019. Me the People: How Populism Transforms Democracy. Cambridge: Harvard University Press.

V-Dem Institute. 2020. Autocratization Surges-Resistance Grows, V-Dem Annual Democracy Report 2020. University of Gothenburg. https://www. v-dem.net/media/filer_public/51/43/51434648-2383-4569-84d0-e02fbd 834b3e/v-dem_democracyreport2020_20-03-18_final_lowres.pdf. Accessed 9 April 2020.

Verba, Sidney, and G.A. Almond. 1963. The Civic Culture: Political Attitudes and Democracy in Five Nations. Princeton, NJ: Princeton University Press.

Waldner, D., and E. Lust. 2018. Unwelcome Change: Coming to Terms with Democratic Backsliding. Annual Review of Political Science 21: 93-113. 
Wilkin, Peter. 2018. The Rise of 'Illiberal' Democracy: The Orbánization of Hungarian Political Culture. Journal of World-Systems Research 24 (1): 5-42. https://doi.org/10.5195/jwsr.2018.716.

Yakovlev, E., and E. Zhuravskaya. 2006. State Capture: From Yeltsin to Putin. CEFIR/NES Working Paper Series, Paper No 94.

Open Access This chapter is licensed under the terms of the Creative Commons Attribution 4.0 International License (http://creativecommons.org/licenses/ by $/ 4.0 /)$, which permits use, sharing, adaptation, distribution and reproduction in any medium or format, as long as you give appropriate credit to the original author(s) and the source, provide a link to the Creative Commons license and indicate if changes were made.

The images or other third party material in this chapter are included in the chapter's Creative Commons license, unless indicated otherwise in a credit line to the material. If material is not included in the chapter's Creative Commons license and your intended use is not permitted by statutory regulation or exceeds the permitted use, you will need to obtain permission directly from the copyright holder.

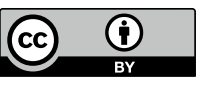

